\title{
Article \\ Renovation of Modernist Architecture Study Based on Selected Cases
}

\author{
Joanna Jablonska *(D) and Lukasz Wojciechowski
}

\footnotetext{
check for updates

Citation: Jablonska, J.;

Wojciechowski, L. Renovation of

Modernist Architecture Study Based

on Selected Cases. Buildings 2022, 12,

195. https://doi.org/10.3390/

buildings12020195

Academic Editors: Paulo Santos

and Mark Bomberg

Received: 10 December 2021

Accepted: 5 February 2022

Published: 8 February 2022

Publisher's Note: MDPI stays neutral with regard to jurisdictional claims in published maps and institutional affiliations.
}

Copyright: (C) 2022 by the authors. Licensee MDPI, Basel, Switzerland. This article is an open access article distributed under the terms and conditions of the Creative Commons Attribution (CC BY) license (https:// creativecommons.org/licenses/by/ $4.0 /)$.
Faculty of Architecture, Wroclaw University of Science and Technology, 50-370 Wroclaw, Poland; lukasz.wojciechowski@pwr.edu.pl

* Correspondence: joanna.jablonska@pwr.edu.pl

\begin{abstract}
Modernist architecture is one of the most significant movements which serve as grounds for contemporary creations. At the beginning of the 20th century, the impact of new structural and building technologies allowed designers to find new ways of architectural expression. It is rooted in thought-out composition and simplicity which serve as a background for the exposition of structure. The geometrical interplay of a building's elements highlights the impressively thin structures and raw surfaces of novel building materials. Nowadays, in selected regions, the architecture of the Modernist Period is neglected or loosely refurbished. As an effect of this phenomenon, buildings are demolished or deprived of aesthetical values. Thus, this article aims at showing an overview of sectional research on good practice. We base the study of on-site design implementations of several modernist architecture refurbishments and focus on technology and design assumptions with optimised thermal modernisation. The paper reveals a set of examples for the refurbishment of modernist architecture, with calculations of heat energy coefficients of the initial and design phase. The presented thermal modernisations aim at adjusting buildings to new requirements concerning energy without any loss of initial architectural expression.
\end{abstract}

Keywords: modernist architecture; thermal refurbishment; monument preservation; energy reduction; architectural up-cycling

\section{Introduction}

The need for post-war modernist architecture preservation is a relatively new concept (especially in Poland, where socialist architecture is still neglected), which arose together with an increase of awareness on sustainability and appreciation for iconic solutions [1,2]. The Modern Period, based on a separation between past and present or enlightenment and individualism [3], made a significant impact on European society. The architecture responding to logical engineering [1] offered more than living and workspace [4]. Nowadays, we admire the interplay of forms and proportions, intelligent space management, and the beauty rooted in modesty $[5,6]$. Though occasionally problematic, modernist buildings require skillful preservation highlighting their qualities.

As Giulian and Bucchignani [7] indicate, the post-war modernist architecture initially was not planned for durability in many cases-especially in the socialist countries where the building techniques, economy and low quality materials and bad craftsmanship lead to many faults of ready buildings (i.e., problems with insulation, overheating, soundproofing, structural joints and reinforcement protection). Thus, nowadays these buildings are perceived as badly ageing and easy to demolish [4]. Post-war modern architecture is a fragile heritage. Most of the buildings in Poland were made of low-quality materials without precision or proper attention to detail. In the minds of people, they represent the creation of the faulty political and economic system. The public does not value this heritage, and some historians and architects neglect it. Architectural values of the Modernist Period in Poland require a sensitive eye, imagination and knowledge to see the initial ideas due to 
the damages in these buildings-done in the process of careless maintenance and renovation (most of which took place in the 1990s and the 2000s).

Also, a misconception of initial ideas and the apartment crisis in Europe after WWII led to building a lot and poorly [8]. There are a lot of issues involved in the preservation of modernist architecture, starting from novel changes in the lifestyle of users [7], through imperfect technology of flat roofs [1], lack of shading [2], to excessive energy consumption [9]. Especially the latter is crucial in terms of European Union policies, like the New European Bauhaus [10] or Renovation wave [11]. Moreover, the European Green Deal initiative aims at the reduction of greenhouse gas emissions by $55 \%$ by the year 2030 , and totally by 2050 [12]. All recalled documents highlight that refurbishment investment must be sustainable [9]. According to Sonnleithner [13] and European Union recommendations [10] of high quality, such an approach is advisable, for it favours architectural recycling, instead of raising new, and at occasions redundant, buildings [7,14]. Also crucial may be the economic aspect, bringing substantial savings [14].

The refurbishment issue of modern architecture is present in scientific discourse. Seen from many angles, it always shows a local reference. A good example is an elaboration of Mulfarth et al. [2] on tall buildings from Sao Paulo; Urbanik and Tomaszewicz's [1] article on flat roof renovation in Wroclaw; and Peters' [14] publication on housing in Denmark. Yet, Pikas et al. [9] indicate that lack of knowledge is one of the barriers to the renovation of modernist (standardised) apartment buildings. The literature insufficiency is understandable, for each region (climatic zone) requires different handling the refurbishment design. Therefore, each published case study provides valuable information for understanding the complex issues of renovation (whether successful or not) and allows for the exchange of knowledge. Sonnleithner [13], p. 5 states: "In the search for goal-oriented approaches to solutions and specific action steps, the development of new concepts and research into previously unknown facts are essential. The experience and familiarity with previous activities, experiments, initiatives and projects from history are valuable. Particularly in the field of building renovation [ ... ], a look into the past might help to ensure a clear view of possible solutions for the future." Thus, in the article, we present a practical (implemented) approach from Wroclaw (Poland) regarding the renovation of a few modernist buildings. In this way, we add another portion of practical knowledge into the discourse. The crucial aspect of the presentation is to propose solutions not interfering with the architectural and aesthetic values of modernist architecture.

The article aims at presenting designed and implemented solutions for the thermal renovation of modernist architecture. This aspect is especially valid because $75 \%$ of buildings in Europe are not energy efficient [11]. Moreover, the literature describes successful modernist implementations where energy consumption decreased significantly, i.e., Brazilian cases by Mulfarth et al. [2]. In general, our goal was following Boza-Kiss et al. [15], p. 7. "decarbonizing the European building stock" —at least a part of it.

\section{Materials and Methods}

The case studies for the article are the works of the architectural office VROA Architekci co-owned by one of the authors of this publication. Lukasz Wojciechowski is the co-author of all the presented projects (as listed in each case). There were several criteria for case studies selection. First of all, these are the examples aiming at keeping the material and formal integrity of modernist architecture-the main goal of the renovations is not to interfere with the original modernist expression of the buildings. We call this aspect architectural criteria. In this respect, the cultural value of the renovated building was crucial [13]. High aesthetics is as important as sustainability and functionality $[10,15,16]$. Other selections criteria were affordability [10], availability of materials, and building solutions that maintain the high quality [13]. The cost issue is crucial for as Nowogońska and Mielczarek [17], p. 1 state: "Unfortunately, due to the higher costs of renovation and the need to supervise work in historic buildings, many valuable buildings are damaged." To summarise, the criteria are as follows: 
- $\quad$ architectural:

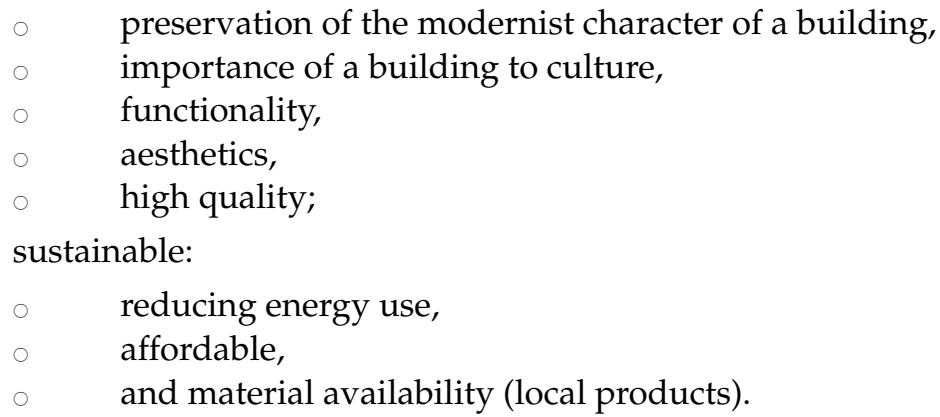

Based on the above, the selected case studies are as listed:

A housing block section by Nankiera Square [18], original design (1969): Włodzimierz Czerechowski, Ryszard Natusiewicz, Anna and Jerzy Tarnawski; renovation design (2015): Agnieszka Hałas, Grzegorz Kaczmarowski, Marta Mnich, and Łukasz Wojciechowski. The complex of the residential towers with the commercial pavilion at Grunwaldzki Square [19,20], original design: Jadwiga Grabowska-Hawrylak, Krzysztof Sasiadek (1968-1978), renovation design (2012): Mnich, Marek Lamber, Natalia Rowińska, Łukasz Wojciechowski, Agnieszka Hałas, Hubert Rozewicz, consultants: Jadwiga Grabowska-Hawrylak, Andreas Wolf.

The restaurant pavilion by the Centennial Hall (UNESCO heritage object) [21], original design (1913): Max Berg; renovation and extension design: Agnieszka Chrzanowska, Marta Mnich, Łukasz Wojciechowski, Wojtek Chrzanowski, in collaboration with Andrzej Chrzanowski, Juliusz Erdman, Grzegorz Kaczmarowski, Danuta Katarasińska, Agata Kurto, Natalia Rowińska, Sebastian Stanisławski.

All buildings are located in Wroclaw (Poland). Selected projects took place in the range of the last ten years.

Thermal refurbishments respond to local law regulations based on the local climate. Citing Climate-data.org [22], conditions in Wroclaw, Poland, are mild and warm, with average temperatures yearly of $10.0^{\circ} \mathrm{C}$, and $700 \mathrm{~mm}$ of rainfall. The average temperature ranges between $20.1^{\circ} \mathrm{C}$ in July and $-0.4^{\circ} \mathrm{C}$ in January.

First we made a literature and documents review to institute requirements and methods for modern architecture preservation (see the introduction section). Second, we reviewed existing design documentation [19-21]. To make the article universal, we summarised the local climate based on recent data from Climate-data.org [22]. Next, based on current documents like European Union policies [10-12], commissioned energy audits by Bilka [23], and Żurawski [24]-external auditors, also our calculations, we have established the required thermal coefficients for all partitions. Audits were performed by local, licensed professionals, to provide a high quality of elaboration. In calculations, they included the initial structure of compartments and afterwards designed solutions. According to Sonnleithner [13], p. 6, high quality of investment is as important as, following present law demands. The thermal modernization followed Polish thermal regulations-so-called Ordinance Minister of Infrastructure from 2002 [25], and standard [26] these regulations refer to general building solutions. However the renovated heritage-listed buildings are excluded from energy efficiency requirements.

The law novelty is crucial as Boza-Kiss et al. [15], p. 11 indicate: "the theoretical consumption of a new building today is about 40\% less than for dwellings built before 1990".

We compared data before and after planned remodeling based on the figures included in energy audits for each building, done before and after the refurbishment process (first two examples). For other cases, we made before and after calculations. All values before and after presented in this article are based on pre-design and post-design calculations. We plan to evaluate buildings further after compilation of all construction works. Presentation of each implementation follows the scheme: 
location,

authors of original project and refurbishment,

history,

renovation assumptions,

remodeling solutions,

calculations of energy savings.

There are several factors recalled in the article. Shape factor A/V means, after Lylykangas [27], p. 4: "the ratio between the outside surface area of the thermal insulation in the building envelope (A) and the heated volume (V)."

In this article, European Standard PN-EN ISO 6946:2017 [26] defines the thermal transmittance U. Its value should be as low as possible and is the reciprocal of the thermal resistance of the entire partition [26]:

$$
U=\frac{1}{R_{t o t}}\left[\frac{\mathrm{W}}{\mathrm{m}^{2}} \mathrm{~K}\right]
$$

where:

W-unit: Watt;

m-unit: meter;

K-unit: Kelvin;

$U$-thermal transmittance $\left[\frac{\mathrm{W}}{\mathrm{m}^{2}} \mathrm{~K}\right]$;

$R_{\text {tot }}$-total thermal resistance $\left[\frac{\mathrm{m}^{2} * \mathrm{~K}}{\mathrm{~W}}\right]$;

Thermal total resistance $R_{\text {tot }}$ determines the following formula [26]:

$$
R_{t o t}=R_{s i}+R_{1}+R_{2}+\ldots+R_{n}+R_{s e}\left[\frac{\mathrm{m}^{2} * \mathrm{~K}}{\mathrm{~W}}\right]
$$

where:

$R_{s i}$-is the internal surface resistance $\left[\frac{\mathrm{m}^{2} * \mathrm{~K}}{\mathrm{~W}}\right]$;

$R_{1}+R_{2}+\ldots+R_{n}$-are the design thermal resistance of each layer $\left[\frac{\mathrm{m}^{2} * \mathrm{~K}}{\mathrm{~W}}\right]$;

$n$-is a total number of the designed layers;

$R_{s e}$-is the external surface resistance $\left[\frac{\mathrm{m}^{2} * \mathrm{~K}}{\mathrm{~W}}\right]$;

Surface resistance values depend on air convection through the compartment and are as follows: for Rsi-upwards: 0.1; downwards: 0.17; horisontal: 0.17; for Rse-upwards: 0.04; downwards: 0.04; horizontal: 0.04 , and $\mathrm{R}$ the design thermal resistance of layer determines formula:

$$
R=\frac{d}{\lambda}\left[\frac{\mathrm{m}^{2} * \mathrm{~K}}{\mathrm{~W}}\right]
$$

where:

$d$-thickness of the layer $[\mathrm{m}]$;

$\lambda$-the design thermal conductivity of material $[\mathrm{W} / \mathrm{mK}]$;

The internal temperature adopted is equal to or above $16{ }^{\circ} \mathrm{C}$. The design did not contain air layers over $0.3 \mathrm{~m}$. Therefore, we used a simplified method of calculations according to European Standard PN-EN ISO 6946:2017.

\section{Results}

\subsection{The Block-of-Flats by Nankiera Square-Completed}

Włodzimierz Czerechowski, Ryszard Natusiewicz, Anna and Jerzy Tarnawscy were the authors of the initial design implemented in 1969, which was refurbished by Agnieszka Hałas, Grzegorz Kaczmarowski, Marta Mnich, and Łukasz Wojciechowski in 2015 [18]. The complex by Nankiera and Nowy Targ (the New Market) squares occupies lines of the 
previous historic buildings (demolished during WWII), typical for this part of Wroclaw Old Town. Yet, the past urban tissue replaces now late-modern layouts of free-standing elongated blocks and core buildings (Figure 1). The design was an architectural and political manifestation of freedom from social realism doctrine. However, it still was an element of socialist propaganda and social engineering. Hence, the Old Town area was then occupied by residents of the elite, while blocks were supposed to serve the working class. The thermal modernization of residential substances is valuable, because over 120 million buildings of this type exist in the European Union [15], p. 12. Initially, the buildings had an open plan with movable partition walls. Reinforced structure supplemented brick so-called 'zreanska' and aerated concrete blocks, while the ceilings were constructed from hollow core slabs and slab-on-grade cinder blocks. There were no thermal insulations, and plaster covered the façades. Glass tiles surfaced the inter-widow stripes, which were reminiscent of op-art graphics. The plinths at the service points on the first floor finished with pebbles fixed in mortar, and glass blocks covered the windows in the staircases.
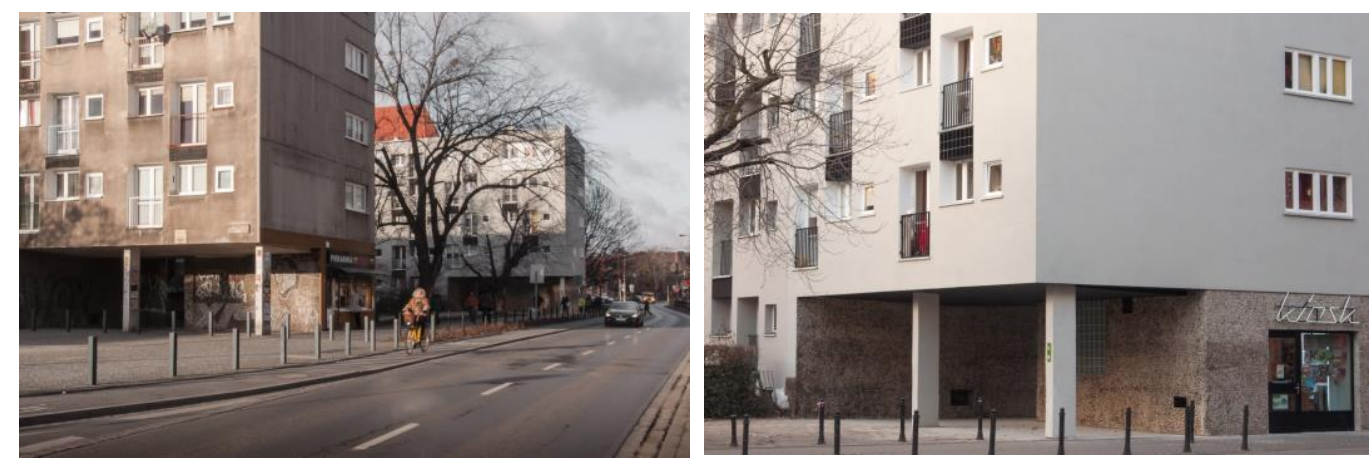

Figure 1. The blocks by Nankiera square-original and refurbished with recreated details (photography by the curtesy of Patryk Kusz/VROA Architekci).

New development founded the municipal company called 'Revitalizations of Wroclaw' (in the Polish language 'Wrocławskie Rewitalizacje'; no longer existing). The renovation included one section of the building and serves as an example for other parts governed by local housing associations. The main goals were thermal modernization and reconstruction of the original block's appearance. However, adding layers, i.e., insulation to the façade, would cause a change in the initial depth of the windows' mounting and would affect in disadvantageous 'puffing' of the architecture. Therefore, the original depth of openings was a priority, and the small windows occupy space on the external wall surface (Figure 2). Other glazed elements mount $15 \mathrm{~cm}$ deep into the façade (also according to the original solution). Flashings, balustrades and glass tiles in the strips between the windows are as close to the original ones as possible. The cladding from pebbles covers the ground floor area as in the original. The ironwork has a graphite colour, and the gable elevation composition crowns a newly designed neon above the entrance to the service point (Figure 1).

We gave detailed original and implemented sections for compartments, and the heat transfer coefficients through partitions-initial and design phase comparison is shown in the below juxtaposition (Table 1) [18]. 

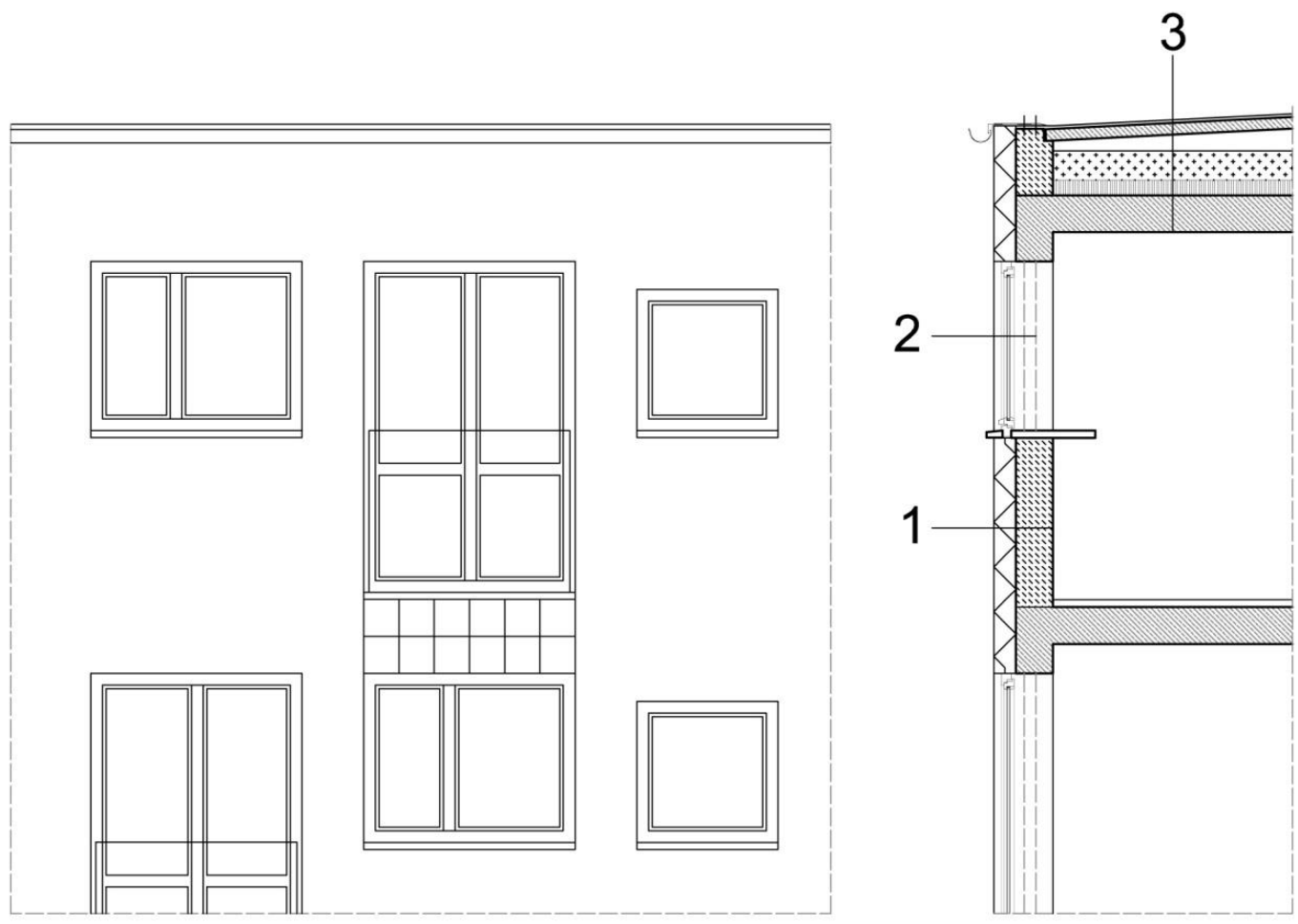

Figure 2. The blocks by Nankiera square-elevation and section. 1. The designed external wall: silicone plaster $1.5 \mathrm{~cm}$, EPS polystyrene $15.0 \mathrm{~cm}$, aerated concrete blocks $24.0 \mathrm{~cm}$, internal plaster $1.5 \mathrm{~cm}$. 2. The depth of the window fixing changed with insulation to preserve the original ratio. 3. The designed roof slab: $2 \times$ roofing felt, levelling layer $2.0 \mathrm{~cm}$, slag concrete slabs in decline $8.0 \mathrm{~cm}$, ventilation gap 10.0, the blow of mineral wool granules $20.0 \mathrm{~cm}$, prefabricated channel slabs $24.0 \mathrm{~cm}$, internal plaster $1.5 \mathrm{~cm}$ (drawn by the Authors).

\subsection{The Façades of Residential Buildings at Grunwaldzki Square-Project, Completed}

Jadwiga Grabowska-Hawrylak and Krzysztof Sasiadek designed the complex of residential buildings with commercial pavilions, plaza and parking spaces (1968-1978). Renovation and thermal modernisation was performed by Marta Mnich, Marek Lamber, Natalia Rowińska, Łukasz Wojciechowski, and Agnieszka Hałas in 2012 with consultations from Jadwiga Grabowska-Hawrylak and Andreas Wolf [19,28]. The document so-called 'The Study of the Conditions and Directions of Spatial Development in Wrocław' protects the complex as a heritage structure of contemporary culture. Also, the List of Monuments of the City of Wrocław includes this development, so design documentation was subject to approval by the Monument Conservator.

The complex consists of six sixteen-story residential towers and service pavilions partially accessible from a raised platform above the garage. A characteristic element of the existing urban layout is a modular $6 \times 6 \mathrm{~m}$ grid, which supports all build substances. The following distinctive element of the project is the façades of residential high-rise buildings, made of individually planned, oval, reinforced concrete prefabricated elements. They are attached to a reinforced concrete skeleton structure of the so-called 'H-frame' type. The space between the prefabricated elements of the façade and the external wall is filled in with loggias. Pots with greenery were supposed to complete this solution, yet this element was omitted in the initial stage of construction [29], (Figure 3). 
Table 1. The thermal modernisation building solutions for the block by Nankiera square (elaborated by the Authors based on [18]).

\begin{tabular}{|c|c|c|c|c|}
\hline No & Name of the Layer & $\begin{array}{l}\text { The Thickness of } \\
\text { the Layer }[\mathrm{cm}]\end{array}$ & $\begin{array}{c}\text { The Design Thermal } \\
\text { Conductivity } \\
\text { of a Material }\end{array}$ & $\begin{array}{l}\text { Heat Transfer Coefficients } \\
\text { through Partition }\left[\frac{\mathrm{W}}{\mathrm{m}^{2}} \mathbf{K}\right]\end{array}$ \\
\hline \multicolumn{5}{|c|}{ The existing external wall (before the mal modernisation) } \\
\hline 1 & $\begin{array}{l}\text { The external plaster } \\
\text { The existing brick }\end{array}$ & 2.0 & 0.82 & \multirow{3}{*}{0.39} \\
\hline 2 & $\begin{array}{l}\text { 'zeranska' / aerated concrete blocks } \\
\text { (porous concrete blocks possible) }\end{array}$ & 24.0 & 0.105 & \\
\hline 3 & The internal plaster & 1.5 & 0.70 & \\
\hline \multicolumn{5}{|c|}{ The designed external wall } \\
\hline 1 & The silicone plaster & 1.5 & 0.7 & \multirow{5}{*}{0.15} \\
\hline 2 & The EPS polystyrene & 15.0 & 0.038 & \\
\hline 3 & The aerated concrete blocks & 24.0 & 0.105 & \\
\hline 4 & The internal plaster & 1.5 & 0.7 & \\
\hline 5 & The silicone plaster & 1.5 & 0.7 & \\
\hline \multicolumn{5}{|c|}{ The existing roof slab } \\
\hline 1 & $\begin{array}{l}2 \times \text { roofing felt (bituminous felt and } \\
\text { tar paper) }\end{array}$ & - & - & \multirow{6}{*}{0.34} \\
\hline 2 & The levelling layer & 2.0 & 1.4 & \\
\hline 4 & The slag concrete slabs in decline & 8.0 & 1.70 & \\
\hline 5 & The ventilation gap & $5.0-30.0$ & $0.16^{1}$ & \\
\hline 6 & The prefabricated channel slabs & 24.0 & 0.18 & \\
\hline 7 & The internal plaster & 1.5 & 1.70 & \\
\hline \multicolumn{5}{|c|}{ The designed roof slab } \\
\hline 1 & $\begin{array}{l}2 \times \text { roofing felt (bituminous felt and } \\
\text { tar paper) }\end{array}$ & - & - & \multirow{7}{*}{0.04} \\
\hline 2 & The levelling layer & 2.0 & 1.4 & \\
\hline 4 & $\begin{array}{l}\text { The slag concrete slabs in decline } \\
\text { (existing) }\end{array}$ & 8.0 & 1.70 & \\
\hline 5 & The ventilation gap (existing) & 10.0 & 0.15 & \\
\hline 6 & $\begin{array}{l}\text { The mineral wool granules injected } \\
\text { into the ventilation gap }\end{array}$ & 20.0 & 0.038 & \\
\hline 7 & $\begin{array}{c}\text { The prefabricated channel slabs } \\
\text { (existing) }\end{array}$ & 24.0 & 0.18 & \\
\hline 8 & The internal plaster & 1.5 & 1.70 & \\
\hline
\end{tabular}

${ }^{1}$ Averaging $15 \mathrm{~cm}$; value from PN-EN ISO 6946:2017.

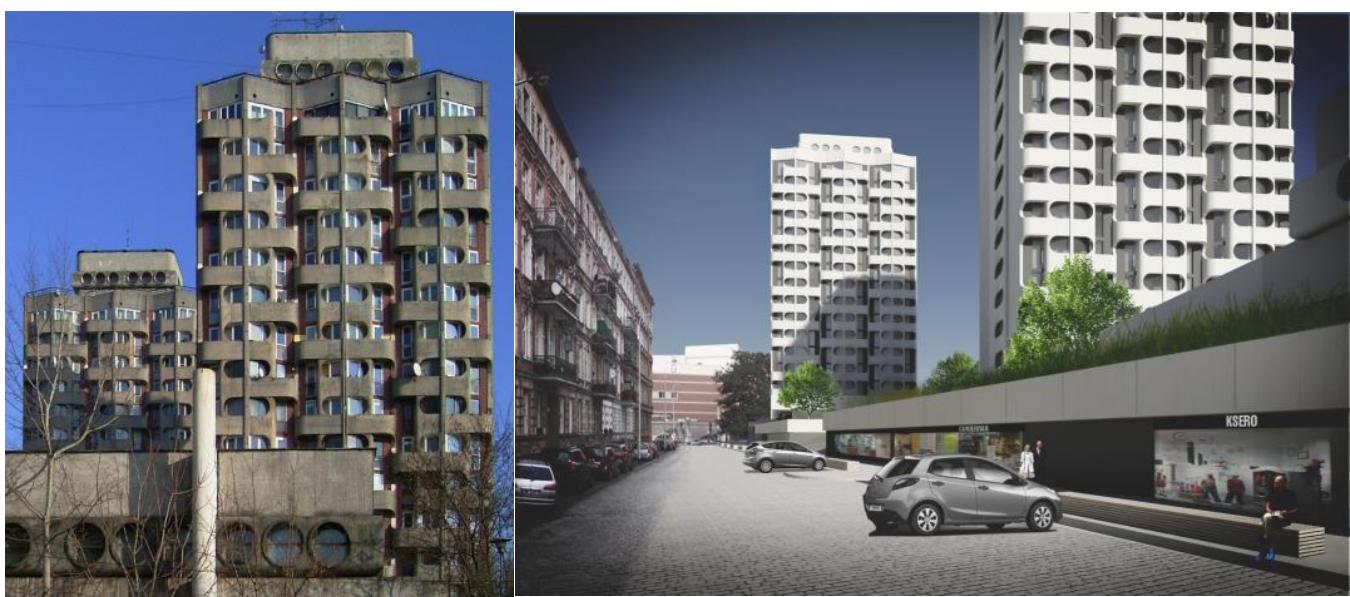

Figure 3. The renovation concept of the façades of residential buildings at Grunwaldzki square-a pre-refurbishment condition in 2007 and remodelling visualisation (photograph by the Authors). 
The renovation aimed to improve the functioning of selected elements of the initial design. This need resulted from new functional requirements not present or predictable in the 1970s. The complex lacked services on the ground floor, required separation of pedestrians and traffic, supply zones and utility yards adjacent to apartment houses. The design included the original proprietary assumptions and consistently used them when expanding, i.e., all additional cubatures were kept in the original 6x6m grid. They also adapted to the existing heights of service pavilions and the pedestrian platform [19].

The most complicated task was to improve the thermal parameters of the residential buildings and their adaptation to the applicable regulations while maintaining the specific architectural values. The concept assumed the necessity of fully preserving the character of the façade made of prefabricated reinforced concrete elements. Thus, external insulation was applied only on the outer walls in the background and gable walls and ceilings. In the case of other parts of the building, the designers proposed inner thermal insulation (Figure 4). This approach enabled the preservation of the initial concept. The façade carvings highlight the colour scheme with white prefabricated elements against a dark background. This decision comes from in-depth analyses of the initial design and consultations with the architect Jadwiga Grabowska-Hawrylak [19].
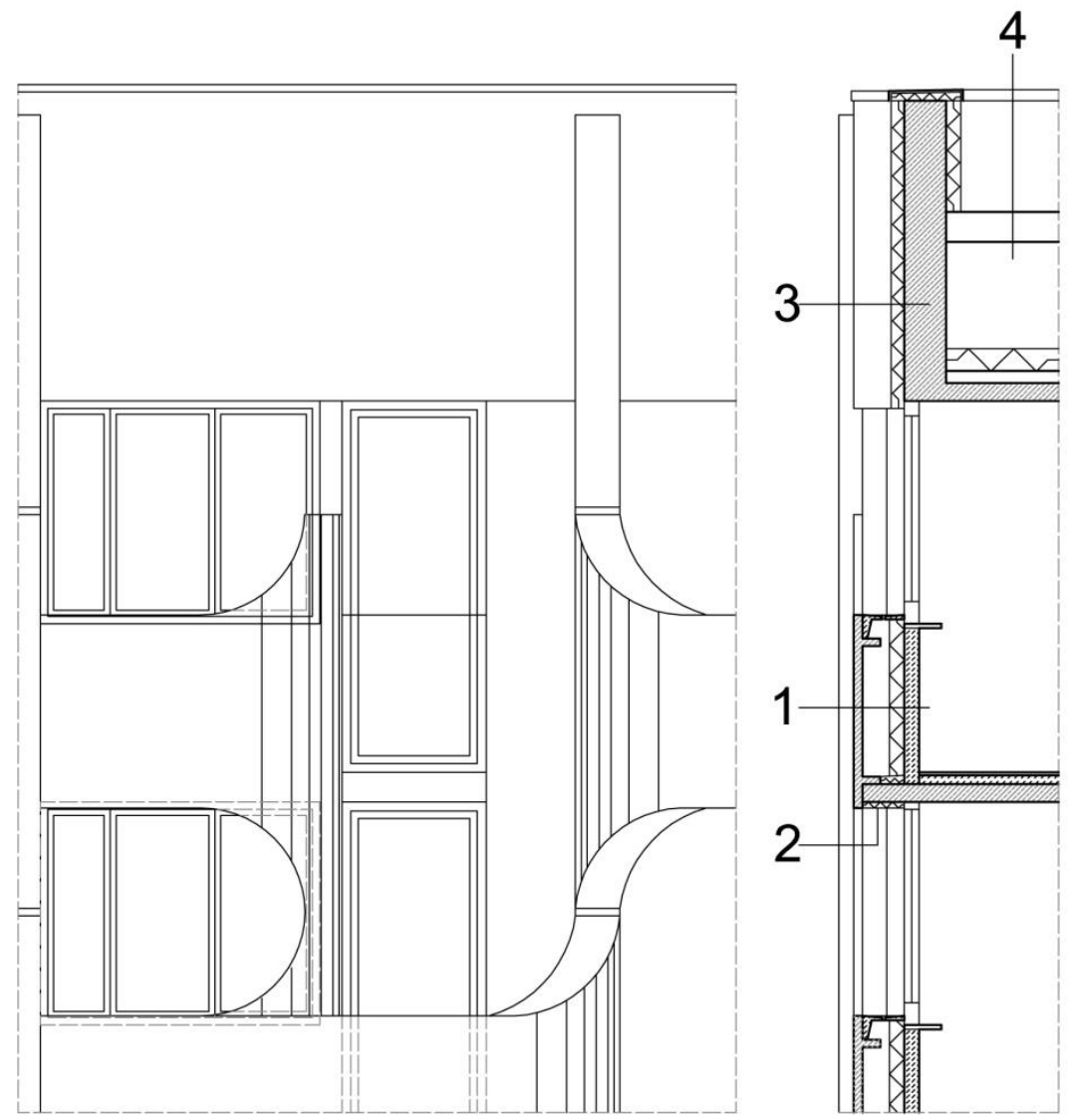

Figure 4. The façades of residential buildings at Grunwaldzki square-elevation and section. 1. The designed external wall (prefabricated): repaired and painted white prefabricates $6.0 \mathrm{~cm}$, external void, mineral wool $8.0 \mathrm{~cm}$, internal walls made of asbestos removed and replaced with light concrete blocks $12.0 \mathrm{~cm}$, internal plaster $1.5 \mathrm{~cm}$. 2. Insulation of loggias-mineral wool. 3. The designed external wall: silicone plaster $1.5 \mathrm{~cm}$, mineral wool $8.0 \mathrm{~cm}$, aerated concrete blocks or reinforced concrete wall $24.0 \mathrm{~cm}$, internal plaster $1.5 \mathrm{~cm}$ (between windows). 4 . The designed roof slab: $2 x$ roofing felt, levelling layer $2.0 \mathrm{~cm}$, slag concrete slabs in decline $8.0 \mathrm{~cm}$, ventilation gap 5.0-30.0 cm, blown-in mineral wool granules in the air cavity $20.0 \mathrm{~cm}$, prefabricated channel slabs $24.0 \mathrm{~cm}$, internal plaster $1.5 \mathrm{~cm}$ (drawn by the Authors). 
The leading assumption of the renovation concept of reinforced concrete facade elements was to restore them to their original appearance. The architects aimed at repairing defects and protection against further destruction and corrosion. It was necessary to strengthen the connections of prefabricated elements with the building structure. The conceptual design assumed cleaning of the prefabricated concrete elements, e.g., by sandblasting, repairing and filling the existing damages. The wall surfaces are painted a light grey colour (Figure 2). The existing clinker tiles are no longer visible, screened with insulation and plaster due to the low budget of the renovation. However, Jadwiga Grabowska-Hawrylak confirmed that she did not plan tiles in the original design of the towers. This solution restores the shade of the light-ash architectural concrete used in the original projects and protects the surface from the harmful effects of weather conditions. However, the assumptions are unfulfilled. The oval prefabricated elements were plastered, which deprived them of the concrete texture. The background wall was covered with paint which is too lightly coloured. We present detailed original and implemented sections for compartments (Table 2) and the changes in their heat transfer coefficients (under the table), [19].

Table 2. The thermal modernisation building solutions for the residential buildings at Grunwaldzki square (elaborated by the Authors based on [19]).

\begin{tabular}{|c|c|c|c|c|}
\hline No & Name of the Layer & $\begin{array}{l}\text { The Thickness of } \\
\text { the Layer }[\mathrm{cm}]\end{array}$ & $\begin{array}{c}\text { The Design Thermal } \\
\text { Conductivity } \\
\text { of a Material }\end{array}$ & $\begin{array}{c}\text { Heat Transfer Coefficients } \\
\text { through Partition }\left[\frac{\mathrm{W}}{\mathrm{m}^{2}} \mathbf{K}\right]\end{array}$ \\
\hline \multicolumn{5}{|c|}{ The existing external wall (between windows) } \\
\hline 1 & The clinker tile & 2.0 & 0.67 & \multirow{4}{*}{0.39} \\
\hline 2 & The ventilation gap & 2.0 & 0.00 & \\
\hline 3 & The aerated concrete blocks & 24.0 & 0.105 & \\
\hline 4 & The internal plaster & 1.5 & 0.7 & \\
\hline \multicolumn{5}{|c|}{ The designed external wall (between windows) } \\
\hline 1 & The silicone plaster & 1.5 & 0.7 & \multirow{4}{*}{0.21} \\
\hline 2 & The mineral wool & 8.0 & 0.035 & \\
\hline 3 & The aerated concrete blocks & 24.0 & 0.105 & \\
\hline 4 & The internal plaster & 1.5 & 0.7 & \\
\hline \multicolumn{5}{|c|}{ The existing roof slab } \\
\hline 1 & $\begin{array}{l}2 \times \text { roofing felt (bituminous felt and } \\
\text { tar paper) }\end{array}$ & - & - & \multirow{6}{*}{0.34} \\
\hline 2 & The levelling layer & 2.0 & 1.4 & \\
\hline 3 & The slag concrete slabs in decline & 8.0 & 1.70 & \\
\hline 4 & The ventilation gap & $5.0-30.0$ & 0.16 & \\
\hline 5 & The prefabricated channel slabs & 24.0 & 0.18 & \\
\hline 6 & The internal plaster & 1.5 & 1.7 & \\
\hline \multicolumn{5}{|c|}{ The designed roof slab } \\
\hline 1 & $\begin{array}{l}2 \times \text { roofing felt (bituminous felt and } \\
\text { tar paper) }\end{array}$ & - & - & \multirow{7}{*}{0.04} \\
\hline 2 & The levelling layer & 2.0 & 1.4 & \\
\hline 3 & The slag concrete slabs in decline & 8.0 & 1.70 & \\
\hline 4 & The ventilation gap & 10 & 0.15 & \\
\hline 5 & $\begin{array}{l}\text { The mineral wool granules injected } \\
\text { into the ventilation gap }\end{array}$ & 20.0 & 0.038 & \\
\hline 6 & The prefabricated channel slabs & 24.0 & 0.18 & \\
\hline 7 & The internal plaster & 1.5 & 1.70 & \\
\hline
\end{tabular}




\subsection{The Commercial Pavillon by Grunwaldzki Square-Project, Not Completed}

The building is a part of the mentioned residential complex. Jadwiga GrabowskaHawrylak, Krzysztof Sasiadek (1968-1978) performed the original design, while Marta Mnich, Łukasz Wojciechowski, Hubert Różycki (2020) drew renovation plans [20]. The pavilion occupies a plot near Grunwaldzki bridge among several commercial spots elevated on a pedestrian platform. The two-story building with a basement has a reinforced concrete structure. Its characteristic spaceship-like façades constitute precast decorative elements with external spiral stairs. The steps wrap around the cylindrical shaft of mechanical ventilation. Glass covers the ground floor façades, divided into three sections with aluminum frames. Above there is the characteristic ornament of an extended curved precast panel with openwork. Circular openings form a repetitive rhythm. Other external walls are opaque and made from aerated concrete, fixed with ceramic tiles and trapezoidal metal sheets (Figure 5), [20].

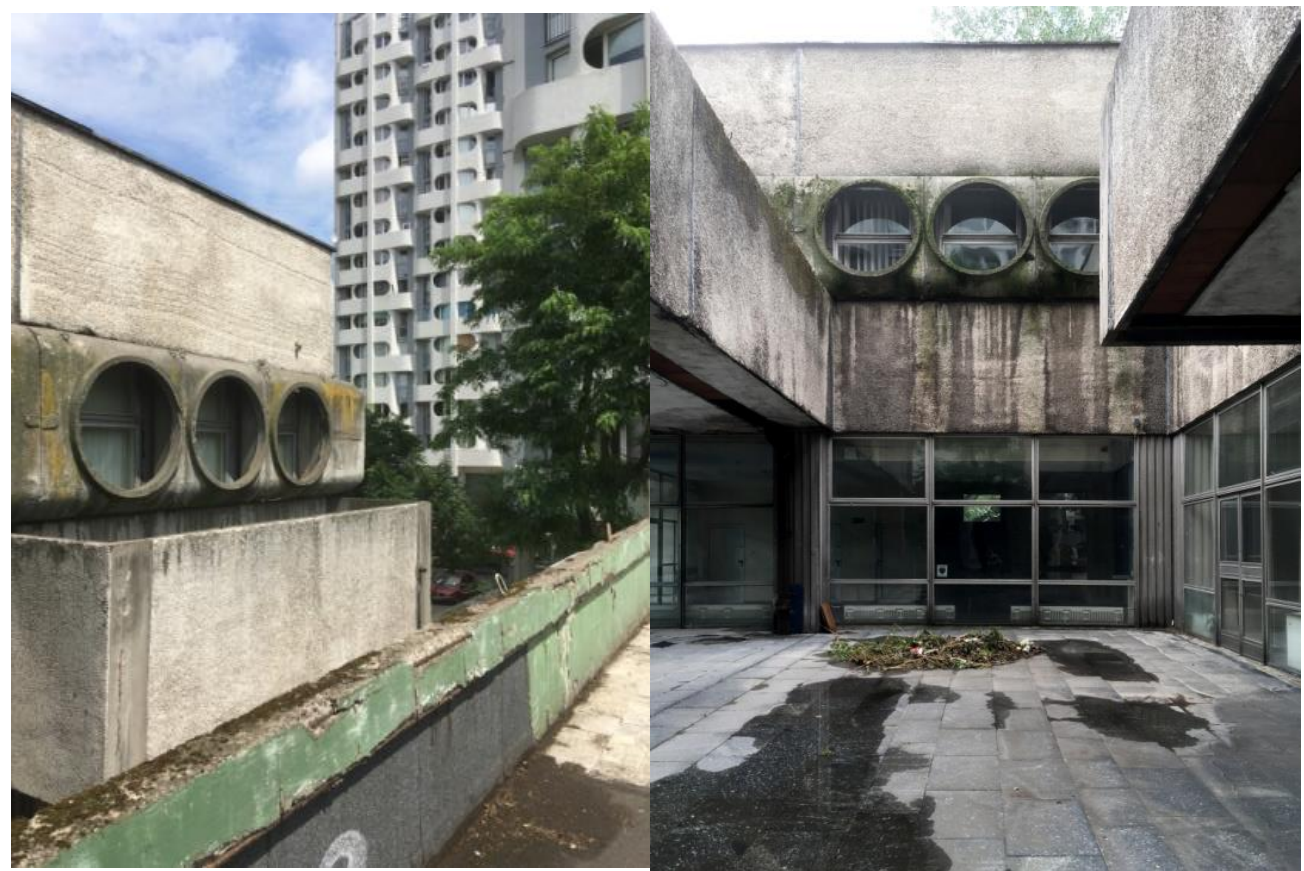

Figure 5. The commercial pavilion by Grunwaldzki Square-the existing condition (photograph by the Authors).

To preserve the initial character of the building, the design of thermal modernisation assumes the internal isolation of opaque walls with mineral boards, the so-called "Multipor" of $5 \mathrm{~cm}$. Concrete pillars-part of the "H-frame" structure-are isolated externally with a $15 \mathrm{~cm}$ layer of Styrofoam boards. The project assumes cleaning of the precast decorative covers and external walls to the original white colour of the concrete. The pavilion's flat roof slab received an additional thermal layer of $20 \mathrm{~cm}$ from Styrodur and required sealing. Architects proposed to keep the original and leaky aluminum frames with glazing by creating an internal glass wall. The solution provides proper thermal conditions, enabling the preservation of the modernist character. Old and new façades will divide a gap for cleaning and the accumulation of passive heat. The aluminum frames on the second floor replace new ones resembling the original (Table 3), (Figure 6), [20]. 
Table 3. The thermal modernisation building solutions for the commercial pavilion at Grunwaldzki square (elaborated by the Authors based on [20]).

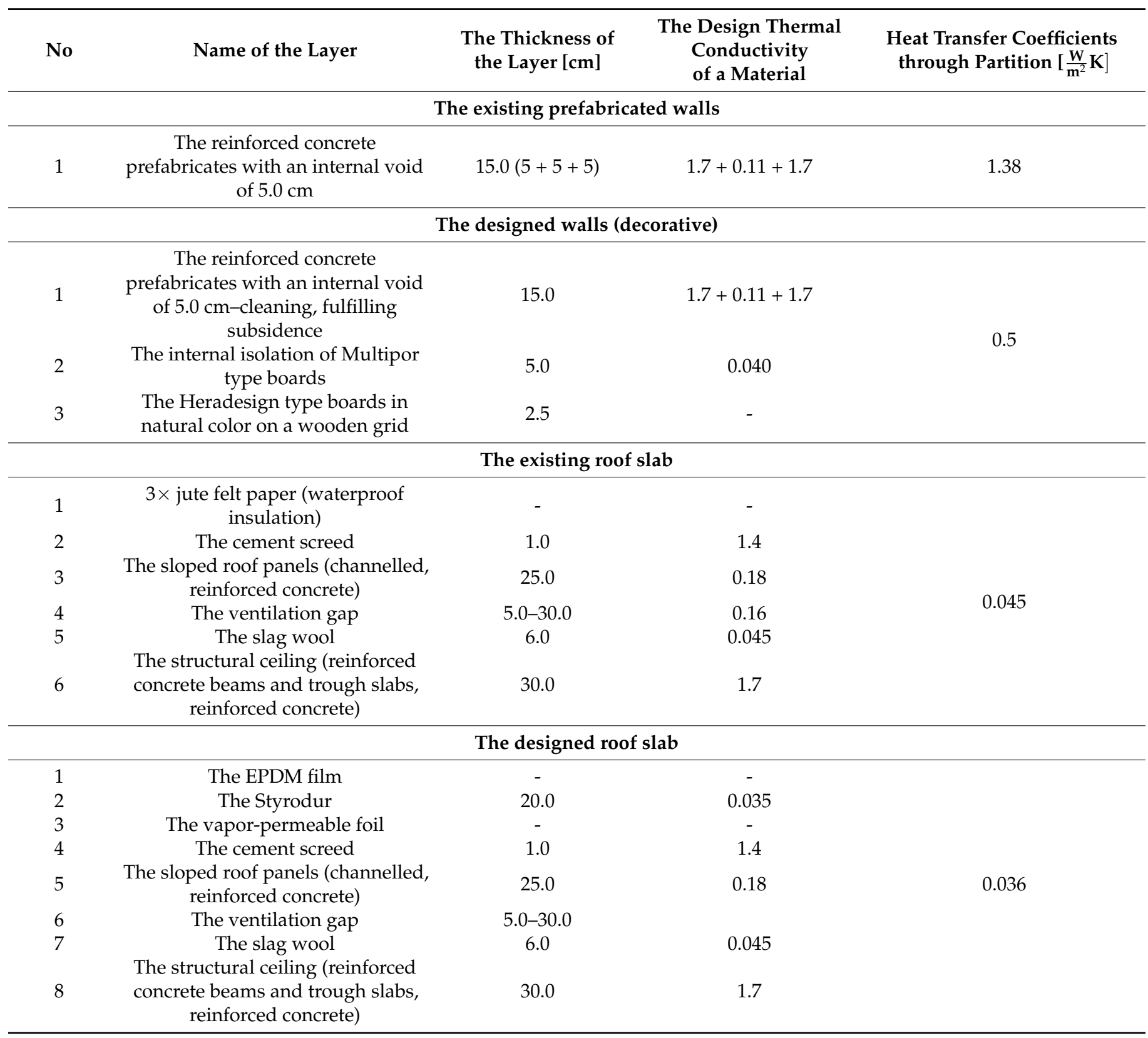

\subsection{Renovation and Extension of the Restaurant Pavilion in the Centennial Hall Complex-Completed}

Max Berg designed the original complex of the Centennial Hall (1913, now under UNESCO protection), while the remodeling and extension (2007-2010) project had the following authors: Agnieszka Chrzanowska, Marta Mnich, Łukasz Wojciechowski, Wojtek Chrzanowski, in collaboration with Andrzej Chrzanowski, Juliusz Erdman, Grzegorz Kaczmarowski, Danuta Katarasińska, Agata Kurto, Natalia Rowińska, and Sebastian Stanisławski [21]. 


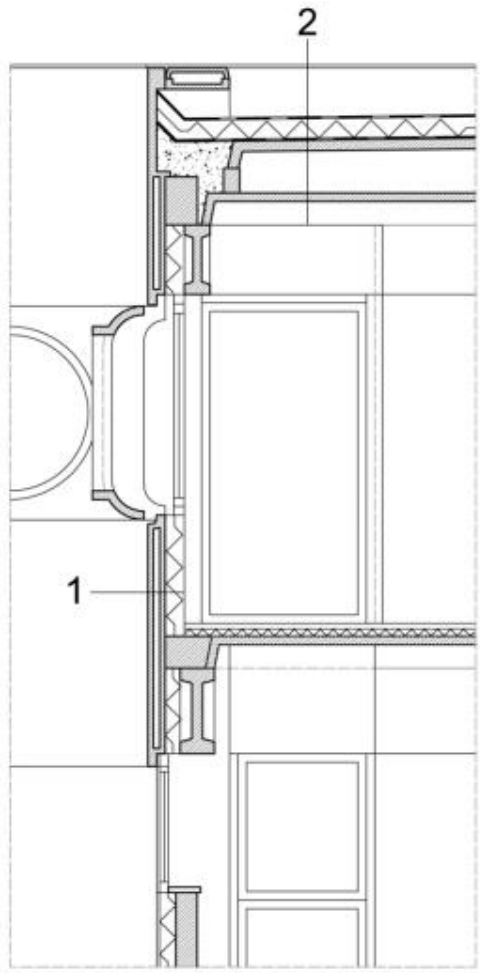

Figure 6. The commercial pavilion by Grunwaldzki Square-section. 1. The designed wall: reinforced concrete prefabricates with an internal void of $5.0 \mathrm{~cm}$-cleaning, fulfilling subsidence $15.0 \mathrm{~cm}$, internal isolation of Multipor-type boards $5.0 \mathrm{~cm}$, and Heradesign-type boards in natural color on a wooden grid $2.5 \mathrm{~cm}$. 2. The designed roof: EPDM film, Styrodur $20.0 \mathrm{~cm}$, vapor-permeable foil, cement screed $1.0 \mathrm{~cm}$, sloped roof panels (channeled, reinforced concrete) $25.0 \mathrm{~cm}$, ventilation gap $5.0-30.0 \mathrm{~cm}$, slag wool $6.0 \mathrm{~cm}$, and structural ceiling (reinforced concrete beams and trough slabs, reinforced concrete) $30.0 \mathrm{~cm}$ (drawn by the Authors).

The pavilion dating to 1913 served as a temporary restaurant and was burnt during WWII. The surviving structure served as an office building in the late 1940s. In 2009 there was a competition held to rebuild and create an extension for a new function as a conference center (Figure 7). The winning concept assumed the preservation of existing and original pavilion elements. Preservation included:

- decorative structural pillars,

- a central lobby with oval skylight,

- a horizontally composed facade across the Centennial Hall.

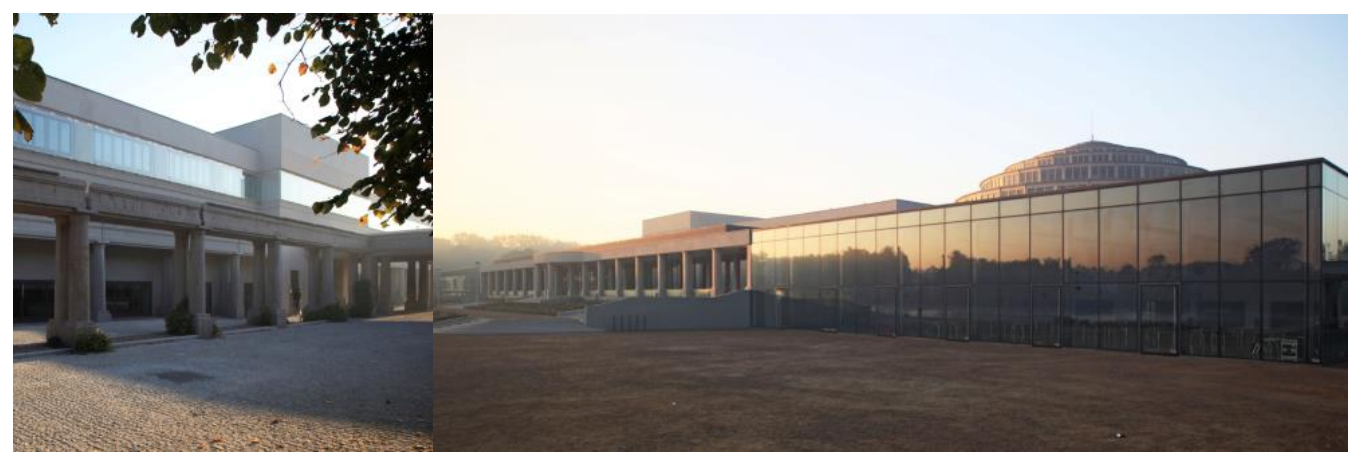

Figure 7. Renovation and refurbishment of the restaurant pavilion of the Centennial Hall complex in Wroclaw-windows and glazed curtain wall (photographs by the Authors). 
Two new and fully glazed wings extend the preserved structure. Cubatures accommodate an auditorium and multifunctional room, while the central part contains a foyer and restaurants, and above - on the mezzanine-office rooms. All technical equipment, storage rooms, service areas, and sanitary areas occupy the underground floor. While the original structure is part load-bearing brick masonry and partly reinforced concrete. It required strengthening of both walls and foundations and a partial change of existing slabs. The new structure was also added, made from steel and founded separately, in the two-story part of the building. The first floor has a light steel structure suspended from the beams of the slab over the floor. The skylight occupying the building's central part is a lightweight structure, as are the new extensions. Plate girders of variable height crown these parts. They have cast foundations of monolith reinforced concrete due to the high levels of groundwater. Opaque walls of existing and new extensions received original materials and colouring. A light-grey structural plaster covers them, polished into an even surface. Preservation of the original composition of façades was a key factor-the columns lean against the external wall. Thus, the remodeling assumed internal insulation. The method also allowed the original depth of the windows to be kept [21].

Due to the high (then) costs of internal thermal insulation systems, the architects proposed individual solutions. These consist of internal gypsum-cardboard walls, vapour barrier foil, mineral wool boards on a steal support sub-structure $(8 \mathrm{~cm}$ width), a ventilation gap, and dimpled foil. Mentioned layers cover an external wall plastered from the outside. The roof slab is insulated transitionally from the exterior (Table 4), (Figure 4), [21].

Table 4. The thermal modernisation building solutions for the restaurant pavilion in the Centennial Hall complex (elaborated by the Authors based on [21]).

\begin{tabular}{|c|c|c|c|c|}
\hline No & Name of the Layer & $\begin{array}{l}\text { The Thickness of } \\
\text { the Layer }[\mathrm{cm}]\end{array}$ & $\begin{array}{c}\text { The Design Thermal } \\
\text { Conductivity } \\
\text { of a Material }\end{array}$ & $\begin{array}{c}\text { Heat Transfer Coefficients } \\
\text { through Partition }\left[\frac{W}{m^{2}} \mathbf{K}\right]\end{array}$ \\
\hline \multicolumn{5}{|c|}{ The existing external wall } \\
\hline 1 & The external plaster & 2.0 & 1.70 & \multirow{3}{*}{1.38} \\
\hline 2 & The full brick wall & 32.0 & 0.77 & \\
\hline 3 & The internal plaster & 1.5 & 1.70 & \\
\hline \multicolumn{5}{|c|}{ The designed external wall } \\
\hline 1 & The thin-layer plaster & 0.3 & 1.70 & \multirow{7}{*}{0.36} \\
\hline 2 & The external cement-lime plaster & 2.0 & 1.70 & \\
\hline 3 & The masonry brick wall & 32.0 & 0.77 & \\
\hline 4 & The dimpled foil & - & - & \\
\hline 5 & The ventilation gap & 2.0 & - & \\
\hline 6 & The mineral wool & 8.0 & 0.038 & \\
\hline 7 & The vapour barrier foil & - & - & \\
\hline \multicolumn{5}{|c|}{ The existing roof slab } \\
\hline 1 & $\begin{array}{l}\text { The existing wooden structure-for } \\
\text { dismantling }\end{array}$ & - & - & - \\
\hline \multicolumn{5}{|c|}{ The designed roof slab } \\
\hline 1 & The SBS modified tar paper & - & - & \multirow{8}{*}{0.04} \\
\hline 2 & The underlay felt paper & - & - & \\
\hline 3 & $\begin{array}{l}\text { The hardboard of mineral wool-for } \\
\text { inclination }\end{array}$ & 5.0-20.0 (avg. 12.5) & 0.038 & \\
\hline 4 & The hardboard of mineral wool & 18.0 & 0.038 & \\
\hline 5 & The vapor barrier & - & - & \\
\hline 6 & $\begin{array}{l}\text { The trapezoidal sheet T55x18 } \\
0.75 \mathrm{~cm}\end{array}$ & - & - & \\
\hline 7 & The steel structure & 30.0 & - & \\
\hline 8 & The fittings gap & 112 & - & \\
\hline
\end{tabular}




\section{Discussion}

The article focuses on the thermal modernisation of modernist architecture while preserving its original aesthesis and composition. This heritage deserves upcycling aiming at the reduction of energy consumption and adjustment to nowadays living standards. We present and analyse case studies of implemented thermal refurbishment designs, which preserve the initial aesthetics of buildings. Selected designs come from the portfolio of one of the article's authors. Another element of the research is the study of energy audits used to establish energy savings. They were as follows:

We calculated exemplary (presented in the article) heat transfer coefficients through construction partitions for the block by Nankiera reduction. We used a simple proportion formula to calculate the thermal transmittance $U$ reduction-between initial and designed values:

$$
\begin{array}{ccc}
\text { initial } U & - & 100 \% \\
\text { the designed } U & - & x \%
\end{array}
$$

And

$$
x=\frac{\text { the designed } U * 100 \%}{\text { initial } U}
$$

Afterwards, we obtained the final value by subtracting $x$ from $100 \%$. The outcome was as follows:

- $\quad$ external walls- $61.53 \%$

- roof- $88.2 \%$.

- Bilka [23] conducted the external energy audit for the initial and design phases. It concerned modification of possible building compartments, ventilation, change of form of heating, etc. The Author [23] analyzed different variants and selected the best one for the investor and the design studio. Based on this document, the shape factor $\mathrm{A} / \mathrm{V}$ was (and is) 0.47. Improvements of mentioned parameters influenced calculated thermal power of the heating system, which initially was $46.66[\mathrm{~kW}]$, and after designed refurbishment achieves 17.52 [kW]. The annual heat demand index to heat the building (without taking into account the efficient heating system and heating interruptions) was $224.54\left[\mathrm{kWh} /\left(\mathrm{m}^{2}\right.\right.$ year $\left.)\right]$ and is 74.57 [kWh/ $\left(\mathrm{m}^{2}\right.$ year $\left.)\right]$, [23]. The Author shows other savings from decreasing heat transfer coefficients for windows-avg. 37\%, doors and gates-34.6\%, the slab over a passage- $91.6 \%$. We expect these parameters once all the construction works are finished according to the recommendations. Data from our calculations and external audits show substantial improvement in building energy performance. At the same time, due to the preservation of the initial structure and adding heat isolation and new coatings, the cost is low. The heat transfer coefficients, through construction partitions, were reduced by a range of $34.6 \%$ to 91.6\% (dependent on the element).

- The calculated thermal power of the heating system was reduced by a range of 26.6-62.4\% (dependent on the case study).

- The annual heat demand index to heat the building (without taking into account the efficient heating system and heating interruptions) reduced by a range of $33.4-66.8 \%$ (dependent on the case study).

These numbers prove that a thermal refurbishment of modernist heritage buildings holds great potential to reduce overall energy consumption in the built environment. Moreover, we show the building solutions that led to the substantial reductions.

For the commercial pavilion at Grunwaldzki square, the values of the heat transfer coefficients' decrease are as listed:

- $\quad$ external walls-46.15\%;

- $\quad$ roof- $88.2 \%$.

As in the previous case for the residential blocks at Grunwaldzki Square, the energy audit was conducted by Żurawski [24]. It considered both the pre-design and post-design 
states, including heating and ventilation cases. Initial shape factor $\mathrm{A} / \mathrm{V}$ was (and is) 0.26 , and the heat transfer coefficients through partitions construction (if construction finishes according to plan), should be reduced by: wooden windows- $48.4 \%$; steel doors (communication) $-57.4 \%$; the slab over a passage (boards) $-79 \%$.

It will influence the calculated thermal power of the heating system, which initially was 425.83 [kW] and after refurbishment achieved 313.20 [kW]. The annual heat demand index to heat the building (without taking into account the efficient heating system and heating interruptions) was 158.92 [kWh/ $\left(\mathrm{m}^{2}\right.$ year $\left.)\right]$ and will be 105.90 [kWh/( $\mathrm{m}^{2}$ year $)$, [24]. The data show improvement in building energy performance.

For the residential buildings at Grunwaldzki Square, values of the heat transfer coefficients' decrease are listed:

- external walls-63.78\%;

- roof- $20 \%$.

For the restaurant pavilion in the Centennial Hall complex the changes are the following:

- $\quad$ external walls-73.91\%;

- Roof was re-designed.

\section{Conclusions}

As stated in the paper, thermal insulation is a crucial issue in the renovation process of modern façades. For instance, the thickness of the insulation layer can change a depth ratio of a wall and a window. The incorrect proportion has a damaging effect on the formal expression of architecture. Some available insulating systems may be more effective than traditional insulations, but new solutions are usually still too expensive to apply and therefore are rejected by clients-as was the case in all the analysed examples. The architects need to consider not only the low budgets offered for the insulation of post-war buildings, but mainly the reluctance of the public and clients to treat them as a proper heritage buildings.

We believe that a substantial number of buildings from the Modern Period deserve renewal. They need inclusion in the architectural and cultural heritage of European cities. What is more, minding that many of that substance is residential, it can fulfil its purpose for years to come. We hope that the article can become part of the discussion and an example of practical solutions in line with sustainable striving and current European Union policies.

Author Contributions: J.J. and L.W. conceptualization, methodology, software, validation, formal analysis, investigation, resources, data curation, writing - original draft preparation, writing-review and editing, visualization, supervision, project administration, funding acquisition. All authors have read and agreed to the published version of the manuscript.

Funding: Subsidy under the program "Initiative of Excellence - Research University (IDUB), budget No: 8211204601 N_RRB_PODST_BAD_EXP_BAM.

Institutional Review Board Statement: Not applicable.

Informed Consent Statement: Not applicable.

Data Availability Statement: Not applicable.

Conflicts of Interest: The authors declare no conflict of interest.

\section{References}

1. Urbanik, J.; Tomaszewicz, A. Flat Roof-Advantage or Disadvantage of Modern Movement Buildings. In Proceedings of the SAHC2014-9th International Conference on Structural Analysis of Historical Constructions, Mexico City, Mexico, 14-17 October 2014; Peña, F., Chávez, M., Eds.; 2014. Available online: https:/ /www.researchgate.net/publication/343294962_Flat_Roof_-_ Advantage_or_Disadvantage_of_Modern_Movement_Buildings (accessed on 8 September 2021).

2. Mulfarth, R.C.K.; Gonçalves, J.C.S.; Michalski, R.L.X.N.; Shimomura, A.R.P.; e Souza, B.N.; Cunha, G.R.M.; Marcondes-Cavaleri, M.P.; Monroy, M.A.G. The environmental response of office buildings from the Brazilian bioclimatic modernism in São Paulo: The case study of Complexo Conjunto Nacional-CCN (1962). Sol. Energy 2021, 220, 617-634. [CrossRef] 
3. Kahraman, A.D. Relationship of modernism, postmodernism and reflections of it on education. Procedia Soc. Behav. Sci. 2015, 174, 3991-3996. [CrossRef]

4. $\quad$ Springer, F. Źle Urodzone (in English Language: Badly Borne); Karakter: Cracov, Poland, 2017.

5. Gabiś, A. Całe Morze Budowania. Wrocławska architektura 1956-1970 (in English Language: The Whole Sea of Buiding. The Architecture of Wroclaw 1956-1970); Museum of Architecture in Wroclaw: Wroclaw, Poland, 2018.

6. Elser, O.; Kurz, P.; Schmal, P. SOS Brutalism. A Global Survey; Park Books: Zürich, Switzerland, 2018.

7. Giuliani, M.V.; Bucchignani, V. Preservation through change: Renovating modern architecture. J. Archit. Plan. Res. 2000, 17, 34-46.

8. Mika, P. The nature of the technology in which the basic executive component is the precasted element. In Proceedings of the 4th International Multidisciplinary Scientific Conference on Social Sciences and Arts SGEM 2017, Albena, Bulgaria, 24-30 August 2017; Volume 17, pp. 823-830. [CrossRef]

9. Pikas, E.; Seppänen, O.; Koskela, L.; Peltokorpi, A. Challenges in Industrialized Renovation of Apartment Buildings. In Proceedings of the 29th Annual Conference of the International Group for Lean Construction (IGLC29), Lima, Peru, 14-17 July 2021; Alarcon, L.F., González, V.A., Eds.; pp. 985-994. [CrossRef]

10. European Commission. A European Green Deal. 2021. Available online: https://ec.europa.eu/info/strategy/priorities-2019-202 4/european-green-deal_en (accessed on 8 September 2021).

11. European Comission. Renovation Wave. 2021. Available online: https:/ / ec.europa.eu/energy/topics/energy-efficiency/energyefficient-buildings/renovation-wave_en (accessed on 8 September 2021).

12. European Commission. New European Bauhaus: Commission Launches Design Phase. 2021. Available online: https://ec.europa. $\mathrm{eu} /$ commission/presscorner/detail/en/IP_21_111 (accessed on 8 September 2021).

13. Sonnleithner, M. New Opportunities for Increasing the Renovation Rate of Buildings. Archit. Pap. Fac. Archit. Des. STU 2021, 26, 2-9. [CrossRef]

14. Peters, T. Architectural Interventions For Social Sustainability: The Renovation Of Modern Housing. In Proceedings of the Regenerative and Resilient Urban Environment, Sustainable Built Environment, Toronto, ON, Canada, 19-20 September 2016; Available online: https://www.researchgate.net/publication/308702873_Architectural_Interventions_For_Social_Sustainability_ The_Renovation_Of_Modern_Housing (accessed on 21 September 2021).

15. Boza-Kiss, B.; Bertoldi, P.; Nives, D.V.; Economidou, M. One-stop shops for residential building energy renovation in the EU. In Analysis \& Policy Recommendations; JRC Science for Policy Report [JRC125380]; Publications Office of the European Union: Luxembourg, 2021. [CrossRef]

16. Sugár, V.; Talamon, A.; Horkai, A.; Kita, M. Energy saving retrofit in a heritage district: The case of the Budapest. J. Build. Eng. 2020, 27, 100982. [CrossRef]

17. Nowogońska, B.; Mielczarek, M. Renovation Management Method in Neglected Buildings. Sustainability 2021, 13, 929. [CrossRef]

18. Mnich, M.; Hałas, A.; Kaczmarowski, G.; Wojciechowski, Ł.; (Wrocław, Poland). Renovation and Reconstruction of a Residential and Service Building Nankiera 14, Wrocław. Personal communication, 2015.

19. Mnich, M.; Wojciechowski, Ł.; Hałas, A.; Rowińska, N.; Wolf, A.; (Wrocław, Poland). The Concept of Revalorization of a Residential and Service Complex Plac Grunwaldzki, Wrocław. Personal communication, 2012.

20. Mnich, M.; Wojciechowski, Ł.; Różycki, H.; (Wrocław, Poland). Renovation and Reconstruction of the Office and Commercial Building with the Conversion of the Basement into an Office and Training Function and Land Development Plac Grunwaldzki, Wrocław. Personal communication, 2020.

21. Mnich, M.; Wojciechowski, Ł.; Chrzanowska, A.; Chrzanowski, W.; Chrzanowski, A.; (Wrocław, Poland). Establishment of the Regional Center for Business Tourism, ul. Wystawowa 1, Wrocław. Personal communication, 2008.

22. Climate-data.org. Climate Wrocław (Poland). 2021. Available online: https://en.climate-data.org/europe/poland/lowersilesian-voivodeship/wroc\%C5\%82aw-4531/ (accessed on 21 September 2021).

23. Bilka, P.; (Wrocław, Poland). Pracownia Projektowa (transl. from Polish Language: The Design Studio) BILAN Paweł Bilka: The Energy Audit for Nankiera 14 Building in Wroclaw. Personal communication, 2015.

24. Żurawski, J.; (Wrocław, Poland). The Energy Audit for Thermal Modernization Enterprise for Implementation at the Basis of Act at 11 November 2008. Personal communication, 2012.

25. Ordinance Minister of Infrastructure of April 12, 2002 on the Technical Conditions to Be Met by Buildings and Their Location, Journal of Laws 2019.1065, i.e of 2019.06.07, Based on Article. 7 sec. 2 point 1 of the Act of July 7, 1994-Construction Law (Journal of Laws of 2018, item 1202, as Amended); Valid at the Date of the Project. Available online: https://www.gov.pl/web/ infrastruktura/warunki-techniczne2 (accessed on 14 October 2021).

26. PN-EN ISO 6946:2017 Building Components and Building Elements-Thermal Resistance and Thermal TransmittanceCalculation Methods, European Standard, Available by: Polish Normalisation Committee (Polski Komitet Normalizacyjny). Available online: https:/ /sklep.pkn.pl/pn-en-iso-6946-2017-10e.html (accessed on 15 January 2022).

27. Lylykangas, K. Shape Factor as an Indicator of Heating Energy Demand, 15. Internationales Holzbau-Forum 09. 2009. Available online: https:/ / www.forum-holzbau.com/pdf/ihf09_Lylykangas.pdf (accessed on 10 November 2021).

28. Wolf, A. Post-war Modernism 2.0 von VROA-Architekten Wrocław. I. Sonntag (Hr. sgb); Sächsische Akademie der Künste: Dresden, Germany, 2014; pp. 202-207.

29. Duda, M. Patchwork. Architektura Jadwigi Grabowskiej-Hawrylak (Patchwork, The Architecture of Jadwiga Grabowska-Hawrylak); Museum of Architecture in Wroclaw: Wrocław, Poland, 2016. 